\title{
Enhanced Fetal Erythrocyte Carbonic Anhydrase Activity by Hydrocortisone
}

\author{
B. J. RUSSELL, B. LOESEBRINK, AND V. CHERNICK ${ }^{(23)}$ \\ Department of Pediatrics, University of Manitoba, Winnipeg, Manitoba, Canada
}

\section{Extract}

The present experiments were undertaken to study the effect of exogenous corticosteroids on carbonic anhydrase (CA) activity in fetal erythrocytes. Rabbit fetuses from 24 days of gestation to term (31 days) were injected intraperitoneally with either $0.2 \mathrm{ml}$ of $0.9 \%$ saline or $2.5 \mathrm{mg}$ hydrocortisone succinate. Nonoperated, noninjected animals served as controls. Carbonic anhydrase activity measured at $24 \mathrm{hr}$ after injection was increased in the saline-injected group at all ages studied when compared with the noninjected fetuses. A marked increase (2- to 7-fold) in enzyme activity was demonstrated after steroid injection at 24 but not 48 hr after treatment. An increase in CA activity was also demonstrated after incubating fetal erythrocytes for 2,4 , and $8 \mathrm{hr}$ in the presence of hydrocortisone succinate. It is suggested that low $\mathrm{CA}$ activity in infants with hyaline membrane disease (HMD) may reflect lack of enhancement by steroid.

\section{Speculation}

Glucocorticoids are probably important in the enhancement of the development of numerous organ systems, including lung, gut, and blood, in preparation for extrauterine life. Low CA activity in the cord blood of infants with HMD may reflect a lack of steroid activation of a number of fetal enzyme systems, including those necessary for surfactant synthesis.

Carbonic anhydrase is an enzyme that reversibly catalyzes the hydration of carbon dioxide to bicarbonate and hydrogen ions. Early investigations have determined that CA activity is lower in the fetus than in the newborn and that both have values lower than the adult $(1,3,6,18)$. More recently, investigators from the United States have demonstrated that the CA activity in the cord blood of infants with HMD is markedly lower than in infants of the same gestational age without $\operatorname{HMD}(7,8,16)$, although the reason for this remains unknown. However, Logan et al. (10) studied infants with and without HMD and measured CA activity in erythrocytes obtained within the first $24 \mathrm{hr}$ of birth. They found no difference in $\mathrm{CA}$ activity. Several investigators have shown an acceleration of fetal lung maturation by the in vivo administration of corticosteroids $(4,5,9,11,15,20)$. With this in mind, the present study was undertaken to determine whether steroids could also enhance carbonic anhydrase activity in the fetus, and whether this might explain the discrepant results reported for $\mathrm{CA}$ activity in infants with HMD.

\section{METHODS}

Forty-two pregnant New Zealand albino rabbits from 24 to 30 days of gestation were used for this study. The does were mated with two bucks within a 2-hour period and this time was considered to be day 0 of gestation. The rabbits were then removed and kept in separate cages for the duration of the experiment. On the appropriate day, a laparotomy was performed on the adults through a midline incision. The fetal abdomen was identified by palpation and an injection of either $0.2 \mathrm{ml} 0.9 \%$ saline or $2.5 \mathrm{mg}$ hydrocortisone succinate in $0.2 \mathrm{ml}$ saline was made intraperitoneally through the intact uterine wall. The abdominal incision was closed and 24 or $48 \mathrm{hr}$ later, the rabbits were killed by an overdose of sodium pentobarbital. The fetuses were removed from the uterus and the fetal blood collected by decapitation into heparinized tubes. Fetuses from nonoperated pregnant does served as controls.

For the in vitro study, $1 \mathrm{ml}$ heparinized whole blood was incubated in $10 \mathrm{ml} 0.9 \%$ saline with $100 \mathrm{mg}$ glucose at $37^{\circ}$. Hydrocortisone succinate $(50 \mu \mathrm{g})$ was added and CA activity was measured after $2,4,6$, and $8 \mathrm{hr}$ and compared with control blood incubated for the same period of time without the addition of hydrocortisone.

For both the in vivo and in vitro studies the heparinized blood was centrifuged, the serum was discarded, and the erythrocytes were washed three times with cold $0.9 \%$ saline. The cells were then frozen and thawed to cause hemolysis. The hemolysate which remained was diluted appropriately and hemoglobin determination was performed according to the method of stadie (17).

Carbonic anhydrase activity was measured according to a modification of the method of Roughton and Booth (14) as described in detail by Logan et al. (10). The principle of this method is a pH-dependent color change as carbon dioxide is hydrated to bicarbonate and hydrogen ions in the presence of Veronal buffer and an indicator, phenol red. All enzyme activities were measured on ice in a cold room to ensure a constant temperature. Dilutions of the initial hemolysate were made to keep the reaction times for the catalyzed reactions between 30 and 60 sec. Enzyme activity was calculated in the following manner

$$
\text { Enzyme units }=\frac{\mathrm{T} 1-\mathrm{T} 2}{\mathrm{~T} 2} \times \mathrm{F}
$$

where $\mathrm{T} 1=$ time for uncatalyzed reaction; $\mathrm{T} 2=$ time for catalyzed reaction; $F=$ dilution of initial hemolysate. One enzyme unit was considered to be that amount of enzyme required to reduce the reaction time of the uncatalyzed reaction by one-half. The Student $t$-test was used for all statistical comparisons.

\section{RESULTS}

\section{HEMOGLOBIN CONCENTRATION (TABLE I)}

Mean hemoglobin $(\mathrm{Hb})$ concentration decreased with advancing gestation in the noninjected control fetuses (Fig. 1). At 26 days gestation the $\mathrm{Hb}$ concentration (mean $\pm \mathrm{SE}$ ) was $19.04 \pm 1.99$ $\mathrm{g} / 100 \mathrm{ml}$ and by 29 and 30 days of gestation the $\mathrm{Hb}$ had fallen to $15.46 \pm 0.58 \mathrm{~g} / 100 \mathrm{ml}$ and $15.65 \pm 0.75 \mathrm{~g} / 100 \mathrm{ml}$, respectively.

The $\mathrm{Hb}$ concentration found in the fetuses from 26 to 28 days of gestation was not significantly different between the noninjected and saline-injected controls. However, saline injected was associated with a significant elevation in $\mathrm{Hb}$ concentration at $24 \mathrm{hr}$ on days 29 and 30 when compared with the noninjected controls. At 
$24 \mathrm{hr}$ steroid-injected fetuses had significantly lower $\mathrm{Hb}$ concentrations than saline-injected fetuses at 26 to 28 days of gestation $(P<$ $0.001)$. Steroid injection was associated with a similar increase in $\mathrm{Hb}$ concentration as saline injection on day 29 but was increased only at $48 \mathrm{hr}$ on day 30 . At $48 \mathrm{hr}$ after injection $\mathrm{Hb}$ concentration was the same as noninjected controls in both saline and steroidinjected fetuses from 26 to 29 days of gestation but remained elevated on day 30.

\section{CA ACTIVITY (TABLE 2)}

CA activity increased significantly with gestational age in noninjected controls, the major change occurring between days 26 and $27(P<0.001)$ (Fig. 2). At both 24 and $48 \mathrm{hr}$ saline injection was associated with a marked increase in CA activity when compared with nonoperated controls in fetuses of 26,27 and 28 days of gestation. There was no significant change in CA activity at $24 \mathrm{hr}$ in the saline-injected fetuses on days 29 and 30 but by $48 \mathrm{hr}$ CA activity was significantly elevated.

Steroid-injected fetuses had a marked increase in CA activity at $24 \mathrm{hr}$, ranging from 2 - to 7 -fold, at all gestational ages $(P<$ 0.001 ). The greatest response was seen at $24 \mathrm{hr}$ and CA activity had fallen considerably by $48 \mathrm{hr}$. However, CA activity still remained above that of noninjected controls at days 26 through 29 $(P<0.001)$. At 30 days, however, CA activity in the $48-\mathrm{hr}$, steroid-injected fetuses was not significantly different from that of the noninjected controls.

Incubating fetal red cells in the presence of $50 \mu \mathrm{g}$ hydrocortisone was associated with a significant increase in CA activity at 2, 4, and $8 \mathrm{hr}$ but not at $6 \mathrm{hr}$ when compared with controls (Fig. 3). Interestingly, the control incubations also had a significant increase in CA activity with increasing incubation time and we have no explanation for this phenomenon.

\section{DISCUSSION}

We measured hemoglobin concentration in each of the samples in order to express $\mathrm{CA}$ activity per $\mathrm{g} \mathrm{Hb}$. Steroid injection caused a significant drop in $\mathrm{Hb}$ concentration $24 \mathrm{hr}$ after injection on days 26,27 , and 28 . Since saline injection was not associated with this effect, the drop in $\mathrm{Hb}$ may be explained by the known mineral-corticoid activity of hydrocortisone resulting in hemodilution which is not evident by $48 \mathrm{hr}$. We cannot adequately explain the elevation in $\mathrm{Hb}$ concentration at $24 \mathrm{hr}$ on day 29 and at $48 \mathrm{hr}$ on day 30 in both saline- and steroid-injected fetuses. Shift of fluid into the peritoneal cavity resulting in hemoconcentration is unlikely since one would have expected a more profound effect in smaller fetuses at 26 to 28 days which were injected with saline. Despite changes in $\mathrm{Hb}$ concentration the estimation of $\mathrm{CA}$ activity remains valid since activity was expressed per $\mathrm{g} \mathrm{Hb}$. That the enhancement of $\mathrm{CA}$ activity in vivo by steroid was not an artifact was supported by the finding of a similar effect in vitro.

In agreement with previous investigations on human and primate erythrocytes, carbonic anhydrase activity had a tendency to increase as gestation proceeded $(6,8)$. The major increase occurred between days 26 and 27.

At every gestational age studied the level of carbonic anhydrase activity was greater in the saline-injected animals than in the noninjected controls. We have found previously that saline injection was associated with changes in lung enzyme systems in the fetal rabbit (15). It is suggested that either the stress of the operative procedure or the injection per se could cause an increased production of endogenous cortisone, thereby affecting CA activity; this supports the notion that we studied a physiologic rather than a pharmacologic effect of steroid.

Fetal injection of $2.5 \mathrm{mg}$ hydrocortisone was associated with a marked increase in CA activity at $24 \mathrm{hr}$ at all gestational ages studied. CA activity remained elevated at $48 \mathrm{hr}$ on days $26,27,28$, and 29 , but had fallen back to control levels in the near term fetus on day 30 . It is suggested that intrauterine stress may be associated with prolonged enhancement of fetal erythrocyte CA activity, particularly in the immature fetus. To what can we attribute this enhancement of activity with steroid?

Suzuki et al. (19) have demonstrated an increase in erythrocyte carbonic anhydrase activity in male mice after subcutaneous hydrocortisone treatment but not after aldosterone therapy. In the same study, adrenalectomy led to a decrease in erythrocyte enzyme

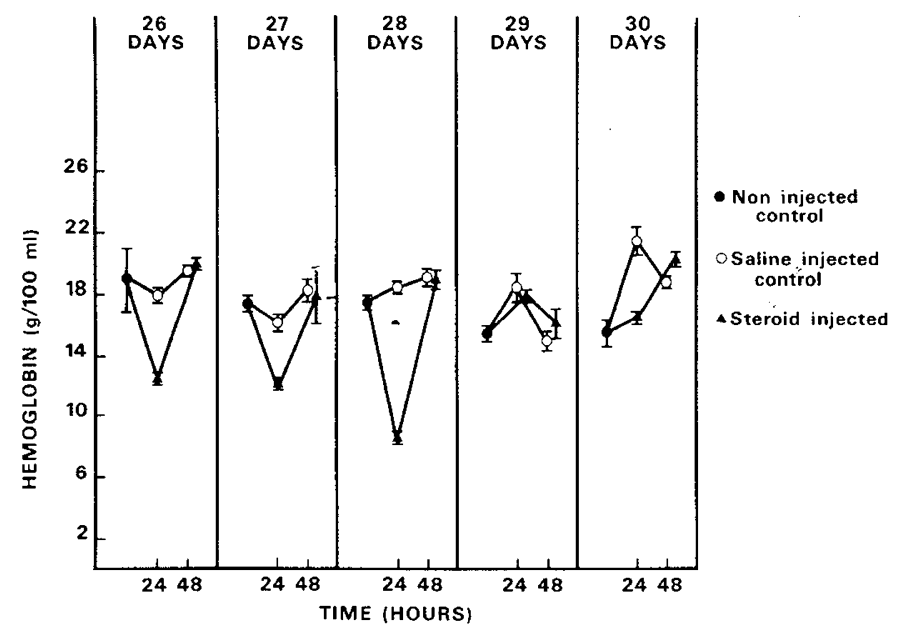

Fig. 1. Relationship (mean $\pm 1 \mathrm{SE}$ ) between hemoglobin concentration and time of death in control fetuses and after saline or steroid injection at each gestational age studied.

Table 1. Mean $( \pm 1 \mathrm{SE})$ hemoglobin concentration $(\mathrm{g} / 100 \mathrm{ml})$ in the five groups of fetuses studied at different gestational ages ${ }^{1}$

\begin{tabular}{|c|c|c|c|c|c|}
\hline $\begin{array}{l}\text { Gestational } \\
\text { age, days }\end{array}$ & Control & $\begin{array}{l}\text { Saline injected, } \\
\qquad 24 \mathrm{hr}\end{array}$ & $\begin{array}{l}\text { Steroid injected, } \\
\qquad 24 \mathrm{hr}\end{array}$ & $\begin{array}{c}\text { Saline injected, } \\
48 \mathrm{hr}\end{array}$ & $\begin{array}{l}\text { Steroid injected, } \\
\qquad 48 \mathrm{hr}\end{array}$ \\
\hline 26 & $\begin{aligned} 19.04 & \pm 1.99 \\
n & =8\end{aligned}$ & $\begin{array}{c}17.98 \pm 0.46 \\
n=14\end{array}$ & $\begin{aligned} 12.69 & \pm 0.15^{2} \\
n & =14\end{aligned}$ & $\begin{aligned} 19.46 & \pm 0.45 \\
n & =10\end{aligned}$ & $\begin{aligned} 20.15 & \pm 0.38 \\
n & =9\end{aligned}$ \\
\hline 27 & $\begin{aligned} 17.49 & \pm 0.57 \\
n & =12\end{aligned}$ & $\begin{aligned} 16.28 & \pm 0.49 \\
n & =15\end{aligned}$ & $\begin{aligned} 12.17 & \pm 0.35^{2} \\
n & =9\end{aligned}$ & $\begin{aligned} 18.34 & \pm 0.81 \\
n & =5\end{aligned}$ & $\begin{aligned} 18.02 & \pm 1.82 \\
n & =5\end{aligned}$ \\
\hline 28 & $\begin{aligned} 17.60 & \pm 0.42 \\
n & =11\end{aligned}$ & $\begin{aligned} 18.47 & \pm 0.35 \\
n & =6\end{aligned}$ & $\begin{aligned} 8.63 & \pm 0.42^{2} \\
n & =7\end{aligned}$ & $\begin{aligned} 19.14 & \pm 0.40 \\
n & =5\end{aligned}$ & $\begin{aligned} 19.01 & \pm 0.55 \\
n & =10\end{aligned}$ \\
\hline 29 & $\begin{aligned} 15.46 & \pm 0.58 \\
n & =6\end{aligned}$ & $\begin{aligned} 18.57 & \pm 0.81^{3} \\
n & =7\end{aligned}$ & $\begin{aligned} 18.01 & \pm 0.43 \\
n & =11\end{aligned}$ & $\begin{aligned} 15.08 & \pm 0.60 \\
n & =5\end{aligned}$ & $\begin{aligned} 16.25 & \pm 0.90 \\
n & =7\end{aligned}$ \\
\hline 30 & $\begin{aligned} 15.65 & \pm 0.75 \\
n & =13\end{aligned}$ & $\begin{aligned} 21.54 & \pm 0.82^{3} \\
n & =7\end{aligned}$ & $\begin{aligned} 16.55 & \pm 0.28^{2} \\
n & =5\end{aligned}$ & $\begin{array}{c}18.75 \pm 0.45 \\
n=8\end{array}$ & $\begin{aligned} 20.32 & \pm 0.57^{2} \\
n & =7\end{aligned}$ \\
\hline
\end{tabular}

\footnotetext{
${ }^{2} n$ : number of fetuses.

${ }^{2}$ Significantly different from saline-injected fetuses.

${ }^{3}$ Significantly different from control fetuses.
} 
Table 2. Mean $( \pm I S E)$ carbonic anhydrase activity (enzyme units $/ \mathrm{g} \mathrm{Hb}) \times 10^{-4}$ in five groups of fetuses studied at different gestational ages

\begin{tabular}{|c|c|c|c|c|c|}
\hline $\begin{array}{l}\text { Gestational } \\
\text { age, days }\end{array}$ & Control & $\begin{array}{l}\text { Saline injected, } \\
\qquad 24 \mathrm{hr}\end{array}$ & $\begin{array}{l}\text { Steroid injected, } \\
\qquad 24 \mathrm{hr}\end{array}$ & $\begin{array}{l}\text { Saline injected, } \\
\qquad 48 \mathrm{hr}\end{array}$ & $\begin{array}{c}\text { Steroid injected, } \\
\qquad 88 \mathrm{hr}\end{array}$ \\
\hline 26 & $\begin{aligned} 0.22 & \pm 0.02 \\
n & =8\end{aligned}$ & $\begin{array}{c}0.70 \pm 0.02^{2} \\
n=14\end{array}$ & $\begin{array}{c}1.59 \pm 0.04^{3} \\
n=14\end{array}$ & $\begin{aligned} 0.72 & \pm 0.04 \\
n & =10\end{aligned}$ & $\begin{aligned} 0.76 & \pm 0.02 \\
n & =9\end{aligned}$ \\
\hline 27 & $\begin{array}{c}0.50 \pm 0.04 \\
n=12\end{array}$ & $\begin{aligned} 0.65 & \pm 0.03^{2} \\
n & =15\end{aligned}$ & $\begin{aligned} 1.49 & \pm 0.06^{3} \\
n & =9\end{aligned}$ & $\begin{aligned} 0.63 & \pm 0.03 \\
n & =5\end{aligned}$ & $\begin{array}{c}0.78 \pm 0.10 \\
\ddot{n}=5\end{array}$ \\
\hline 28 & $\begin{aligned} 0.37 & \pm 0.04 \\
n & =11\end{aligned}$ & $\begin{aligned} 0.76 & \pm 0.05^{2} \\
n & =6\end{aligned}$ & $\begin{aligned} 1.21 & \pm 0.08^{3} \\
n & =7\end{aligned}$ & $\begin{aligned} 0.98 & \pm 0.06 \\
n & =5\end{aligned}$ & $\begin{aligned} 0.79 & \pm 0.03^{3} \\
n & =10\end{aligned}$ \\
\hline 29 & $\begin{aligned} 0.55 & \pm 0.02 \\
n & =6\end{aligned}$ & $\begin{aligned} 0.58 & \pm 0.03 \\
n & =7\end{aligned}$ & $\begin{aligned} 1.22 & \pm 0.08^{3} \\
n & =11\end{aligned}$ & $\begin{aligned} 0.65 & \pm 0.01 \\
n & =5\end{aligned}$ & $\begin{aligned} 0.74 & \pm 0.03 \\
n & =7\end{aligned}$ \\
\hline 30 & $\begin{aligned} 0.56 & \pm 0.02 \\
n & =13\end{aligned}$ & $\begin{aligned} 0.64 & \pm 0.04 \\
n & =7\end{aligned}$ & $\begin{aligned} 1.47 & \pm 0.07^{3} \\
n & =5\end{aligned}$ & $\begin{aligned} 0.90 & \pm 0.06 \\
n & =8\end{aligned}$ & $\begin{aligned} 0.56 & \pm 0.02^{3} \\
n & =7\end{aligned}$ \\
\hline
\end{tabular}

${ }^{1} n$ : number of fetuses.

${ }^{2}$ Significantly different from control fetuses.

${ }^{3}$ Significantly different from saline-injected fetuses.

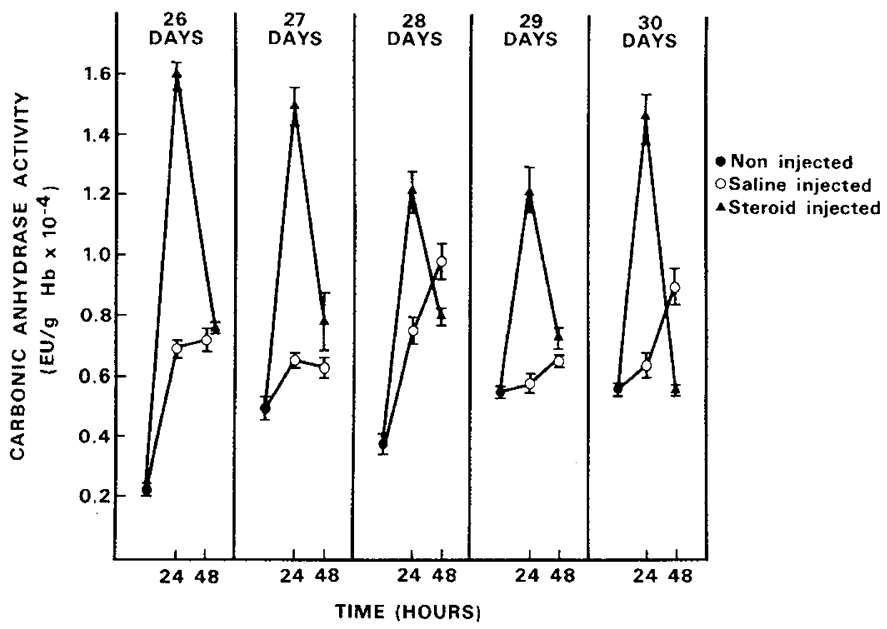

Fig. 2. Relationship (mean $\pm 1 \mathrm{SE}$ ) between carbonic anhydrase activity and time of death in control fetuses and after saline or steroid injection at each gestational age studied. $E U$ : enzyme units.

activity in male rats and mice; however, the level of activity returned to normal after hydrocortisone or aldosterone treatment. The authors concluded that carbonic anhydrase activity was intimately involved with adrenocortical hormone activity but the mechanism remained unclear.

Narumi and Miyamoto (13) have shown that bovine erythrocyte carbonic anhydrase could be activated in vitro in the presence of ATP and $\mathrm{Mg}^{2+}$ by a cyclic AMP-dependent protein kinase. Carbonic anhydrase was phosphorylated by the protein kinase and its reaction was cyclic AMP dependent. It is therefore possible that glucocorticoid enhances fetal erythrocyte CA activity by increasing cyclic AMP, thereby activating protein kinase. However, the precise mechanism of enhanced fetal CA activity by steroid in the present study remains unknown. A study of the relationship between fetal erythrocyte cyclic AMP concentration and CA activity in response to glucocorticoid would be of interest.

Investigations performed previously have shown that the $\mathrm{CA}$ activity in infants with HMD is lower than that found in infants of the same gestational age without $\operatorname{HMD}(7,8,16)$. These investigators studied cord blood samples. Logan et al. (10) studied samples drawn from umbilical vein, artery, or heel capillaries during the first $24 \mathrm{hr}$ of life in healthy, preterm infants and those with HMD and did not find a statistically significant difference in CA activity although the mean value was lower in the infants with HMD. We think these discrepant results might be explained on the basis of postnatal enhancement of erythrocyte $\mathrm{CA}$ activity in infants with

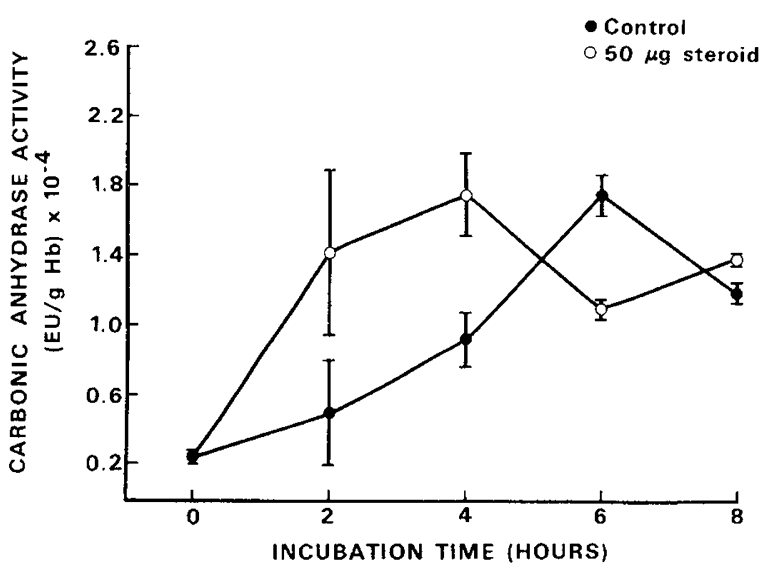

Fig. 3. Relationship (mean $\pm 1 \mathrm{SE}$ ) between erythrocyte carbonic anhydrase activity and time of incubation with and without the addition of hydrocortisone. $E U$ : enzyme units.

HMD since serum cortisol levels have been shown to be low in the cord blood of infants with HMD but elevated after birth $(2,12)$.

\section{SUMMARY}

Injection of hydrocortisone into premature rabbit fetuses (days $26,27,28$, and 29) is associated with enhanced erythrocyte CA activity for at least $48 \mathrm{hr}$. On day 30 this enhancement lasted only $24 \mathrm{hr}$. A similar effect of steroids on CA activity was demonstrated in vitro. It is suggested that the mechanism of enhancement of $C A$ activity may be related to activation of a cyclic AMP-dependent protein kinase. It is tempting to speculate that the low CA activity in the cord blood of infants with HMD reflects lack of steroid activation of a number of fetal enzyme systems, including those necessary for surfactant synthesis.

\section{REFERENCES AND NOTES}

1. Altschule, M. D., and Smith, C. A.: Blood carbonic anhydrase activity in newborn infants and their mothers. Pediatrics, 6: 717 (1950).

2. Baden, M., Bauer, C. R., Colle, E., Klein, G., Papageorgiou, A., and Stern, L.: Plasma corticosteroids in infants with the respiratory distress syndrome. Pediatrics, 52: 782 (1973).

3. Berfenstam, R.: Studies on carbonic anhydrase activity in children. Acta Paediat., 41: 32 (1952).

4. DeLemos, R. A., Shermeta, D. W., Knelson, J. H., Kotas, R., and Avery, M. E. Acceleration of appearance of pulmonary surfactant in the fetal lamb by administration of corticosteroids. Amer. Rev. Resp. Dis., 102: 459 (1970).

5. Farrell, P. M., and Zachman, R. D.: Induction of choline phosphotransferase and lecithin synthesis in the fetal lung by corticosteroids. Science, 179:297 (1973).

6. Fisher, D. A.: Carbonic anhydrase activity in fetal and young rhesus monkeys. Proc. Soc. Exp. Biol. Med., 107: 354 (1961). 
7. Kleinman, L. J., Petering, H. G., and Sutherland, J. M.: Blood carbonic anhydrase activity and zinc concentration in infants with respiratory distress syndrome. N. Eng. J. Med., 277: 1157 (1967).

8. Kleinman, L. J.. Sell, J. E., and Petering, H. G.: Carbonic anhydrase isoenzymes in infants with respiratory distress syndrome. Amer. J. Dis. Child. 124: 696 (1972).

9. Kotas, R. V., and Avery, M. E.: Accelerated appearance of pulmonary surfactant in the fetal rabbit. J. Appl. Physiol., 30: 358 (1971).

10. Logan, R. W., Crooks, S. M., Hutchison, J. H., and Kerr, M. M.: Blood carbonic anhydrase activity in the newborn. Arch. Dis. Childhood, 48: 256 (1973)

11. Motoyama, E. K., Orzalesi, M. M., Kikkawa. Y., Kaibara, M., Wu, B., Zigos, C. J., and Cook, C. D.: Effect of cortisol on the maturation of fetal rabbit lungs. Pediatrics, 38: 547 (1971)

12. Murphy, B. E. P.: Evidence of cortisol deficiency at birth in infants with the respiratory distress syndrome. J. Clin. Endocrinol., 38: 158 (1974).

13. Narumi, S., and Miyamoto, E.: Activation and phosphorylation of carbonic anhydrase by adenosine $3^{\prime} 5^{\prime}$-monophosphate-dependent protein kinases. Biochem. Biophys. Acta, 350: 215 (1974)

14. Roughton, F.J.W., and Booth, V. H.: The effect of substrate concentration, pH, and other factors upon the activity of carbon anhydrase. Biochem. J., 40:319 (1946).

Copyright (C) 1976 International Pediatric Research Foundation, Inc.
15. Russell, B. J., Nugent, L., and Chernick, V.: Effects of steroids on the enzymatic pathways of lecithin production in fetal rabbits. Biol. Neonate, 24: 306 (1974).

16. Sell, J. E., and Petering, H. G.: Carbonic anhydrases from human neonatal erythrocytes. J. Lab. Clin. Med., 84: 369 (1974).

17. Stadie, W. C.: A method for the determination of methemoglobin in blood. J. Biol. Chem., 41: 237 (1920).

18. Stevenson, S. S.: Carbonic anhydrase in newborn infants. J. Clin. Invest., 22: 403 (1943).

19. Suzuki, S., Ogawa, E., and Shibata, K.: Experimental studies on the carbonic anhydrase activity. IX. The mode of action of adrenocortical steroids, especially aldosterone on the carbonic anhydrase in mice and rats. Endocrinol. Jap., 14: 107 (1967).

20. Wang, N. S., Kotas, R. V., Avery, M. E., and Thurlbeck, W. M.: Accelerated appearance of osmiophitic bodies in fetal lungs following steroid injection. $J$. Appl. Physiol., 30: 362 (1971).

21. We are grateful to Mrs. P. Trudel for typing the manuscript.

22. This research was supported by the Medical Research Council of Canada and the Children's Hospital of Winnipeg Research Foundation, Inc.

23. Requests for reprints should be addressed to: V. Chernick, M.D., Children's Centre, 685 Bannatyne Ave., Winnepeg, Manitoba R3E OW1 (Canada).

24. Accepted for publication March 17, 1976.
Bilirubin promethazine induction $\mathrm{Rh}$ erythroblastosis liver

\title{
Spectrophotometric Characteristics of Bilirubin
}

\author{
KWANG-SUN LEE AND LAWRENCE M. GARTNER ${ }^{(43)}$ \\ Department of Pediatrics, Rose F. Kennedy Center and Liver Research Center, Albert Einstein College of Medicine, \\ Bronx, New York
}

\section{Extract}

Spectrophotometric characteristics of bilirubin at low concentrations $(0.005-2.500 \mathrm{mg} / 100 \mathrm{ml})$ have been studied under various physical conditions in order to gain a better understanding of the state of bilirubin when preparing "solutions" for laboratory use. Standing, minimal shaking, or stirring of the bilirubin preparations at $\mathrm{pH} 7.4$ progressively reduced and altered the maximal spectral absorption of bilirubin $(440 \mathrm{~nm})$ in aqueous buffered media. The shift to $415-420 \mathrm{~nm}$ is attributed to oxidation of the pigment whereas shoulder formation is attributed to the formation of large size particles (flocculants). In the presence of antioxidants (L-ascorbic acid and nitrogen gas) and EDTA the maximal absorption peak remained at $440 \mathrm{~nm}$ but decreased in magnitude concomitant with development of a progressively increasing shoulder at $\mathbf{4 8 0}-560$ $\mathrm{nm}$. In the absence of antioxidants and EDT A maximal absorption shifted to $415-420 \mathrm{~nm}$ and the magnitude of $480-560 \mathrm{~nm}$ shoulder formation was less. At the higher concentrations of bilirubin and with reduction in $\mathrm{pH}$ of the buffer in the absence of antioxidants, the shift to lower wave lengths was reduced and $480-560 \mathrm{~nm}$ shoulder formation was increased. In the absence of antioxidants and EDTA at the lower concentrations of bilirubin and in more alkaline media, the reduction at $440 \mathrm{~nm}$ and the shift of maximal absorption to the shorter wave lengths was enhanced. At $\mathrm{pH} \mathrm{12,} \mathrm{stirring} \mathrm{of} \mathrm{anti-}$ oxidant-EDTA-containing solutions of bilirubin resulted in neither a shift of maximal absorption to the shorter wave lengths nor the formation of $480-560 \mathrm{~nm}$ shoulder. The formation of $480-560 \mathrm{~nm}$ shoulder was accompanied by the visual appearance of turbidity. The formation of flocculants when a "solution" is agitated indicates that significant portions of the pigment were in fact, not in solution and must have existed previously as a finely dispersed colloidal sol or supersaturated solution which progressed to a colloidal sol.

Spectral curves of bilirubin, therefore, may represent a composite resulting from four physical states of bilirubin: $(1)$ bilirubin truly in solution with the spectral peak at $440 \mathrm{~nm}$; (2) bilirubin in the fine colloidal dispersion with spectral characteristics similar to those of bilirubin in solution; (3) bilirubin flocculant giving $480-560 \mathrm{~nm}$ shoulder; and (4) oxidation products of bilirubin with the spectral peaks lower than $440 \mathrm{~nm}$.

Increasing the $\mathrm{pH}$ of the aqueous media containing bilirubin $(0.05$ $\mathrm{mg} / 100 \mathrm{ml}$ ) from 7.4 to 12.0 increased the molar extinction coefficient of bilirubin, $E_{440}^{1 \mathrm{M}, 1 \mathrm{~cm}}$, progressively to a maximum at pH 12 of $6.35 \times 10^{4}$. Very dilute bilirubin preparations $(0.005-$ $0.050 \mathrm{mg} / 100 \mathrm{ml}$ ) in aqueous media, $\mathrm{pH} 7.4$, exhibited spectral evidence of rapid oxidation (more so at higher $\mathrm{pH}$ ), but spectral shoulder formation was still observed after mechanical agitation. Thus, the solubility of bilirubin in $0.1 \mathrm{M}$ phosphate buffer at $\mathrm{pH}$ 7.4 appears to be less than $0.005 \mathrm{mg} / 100 \mathrm{ml}$.

\section{Speculation}

Unbound bilirubin in vivo, at concentrations exceeding albumin binding capacity and its aqueous solubility, is believed to exist either as a colloidal sol (micropolymer) or a flocculant (macropolymer). It is proposed that it is in the colloidal sol form (micropolymer) that bilirubin toxicity to brain, kidney, intestinal mucosa, erythrocyte, and other organs initially develops by a process of colloid to surface interaction. 